\title{
REVISTA ESPECIALIZADA E CIÊNCIA
}

\author{
Specialized Journal and Science | Revista especializada y ciencia
}

\author{
Silvânia Siebert* \\ Universidade do Sul de Santa Catarina \\ Programa de Pós-Graduação em Ciências da Linguagem \\ Tubarão, SC, Brasil
}

Mais uma vez, cumprimentamos leitores, consultores, pesquisadores, autores, curiosos, enfim, todos que compartilham o interesse comum pelos estudos da linguagem. No editorial anterior, discutimos o negacionismo científico. O tema - inegavelmente no centro das discussões entre especialistas e no dia a dia da população - ganha mais interesse em tempos nos quais se polemiza a vacinação contra o vírus SARS CoV-2. Em A ciência resiste, Daltoé e Siebert (2021) analisam a partir de uma perspectiva discursiva como a vacina se tornou objeto de disputa de poder e como se faz necessário lutar pela disseminação do saber científico como forma de posicionamento político.

Nesta edição, reforçamos a importância da divulgação científica especializada. De acordo com Santos (2007, p. 37), as revistas especializadas se constituem "lugares privilegiados (no interior do campo) para anunciar resultados, receber contribuições, ouvir críticas submeter a julgamento, etc, visto que, a circulação de novos saberes é importante para dar continuidade ao processo evolutivo do conhecimento". Além disso, cabe a elas o importante papel de oportunizar aproximações de culturas e povos. Esse é precisamente o caso do artigo Análise discursiva do livro didático de inglês da $11^{a}$ classe usado em escolas públicas e privadas de Angola, que abre o conjunto de oito textos inéditos deste fascículo e nos apresneta a análise de um manual de inglês da $11^{\mathrm{a}}$ Classe usado nas escolas de Angola. De autoria do professor e pesquisador Dinis Fernando da Costa, a pesquisa nos mostra como é possível trocarmos ideias e ideais por meio da ciência. Com base na Análise Crítica de Discurso (ACD), o artigo mostra aos leitores da LemD que a representação étnica apresentada de forma assimétrica no livro incentiva estereótipos como preconceitos sociais, étnicos e raciais nos alunos.

Também publicamos neste número o artigo Sobre o político e a resistência no filme o fotógrafo de Mauthausen. Neste estudo, a partir de um diálogo entre a Análise de Discurso e a Semântica do Acontecimento, Wagner Ernesto Jonas Franco põe em cena a narrativa sobre um ex-soldado da Guerra Civil Espanhola preso no campo de concentração de Mauthausen (Áustria) durante a Segunda Guerra Mundial.

\footnotetext{
* Doutora em Linguística Aplicada pela Universidade Estadual de Campinas. Editora de Linguagem em (Dis)curso. ORCID: https://orcid.org/0000-0002-7852-0968. E-mail: silvania@cinemaistv.com.br
} 
No artigo "E agora, José?": manchetes, lides e a gramática da (in)visibilização social, Roseli Gonçalves do Nascimento usa as ferramentas do sistema de transitividade da gramática sistêmico-funcional e da taxonomia de representação de eventos sociais para verificar como a mídia recontextualiza o evento social e seus atores de modo a construir representações particulares sobre eles.

Em Considerações sobre pesquisa e gêneros discursivos para a educação básica, Luiz Antônio Ribeiro e Cláudia Mara de Souza propõem refletir, a partir das abordagens bakhtiniana e swalesiana de gêneros discursivos, a necessidade de inserção de práticas de pesquisa e de gêneros discursivos nas escolas de educação básica e nas instituições de ensino superior.

No texto, Condições de leitura, recepção e exegese da obra bakhtiniana no Brasil, Nathan Bastos de Souza, Gabriella Cristina Vaz Camargo, Grenissa Bonvino Stafuzza apresentam elementos sobre as condições de leitura, recepção e exegese da obra bakhtiniana no Brasil.

Os contrastes de Ciça: explorando os ethé da cartunista brasileira, escrito por Ana Cristina Carmelino e Paulo Ramos, usa as lentes da Retórica e da Nova Retórica, para mostrar a construção dos ethé de Ciça, cartunista e autora das tiras cômicas $O$ Pato, publicadas durante a Ditadura Militar brasileira (1964-1985) no jornal Folha de S. Paulo.

$O$ discurso sobre a abertura das universidades brasileiras às migrações contemporâneas no jornalismo digital, artigo realizado por Marluza da Rosa analisa a partir do olhar teórico-metodológico dos estudos do discurso franco-brasileiros o funcionamento do discurso jornalístico sobre o acesso de estudantes refugiados(as) ao ensino superior brasileiro.

Arquitetura do processamento cognitivo: efeito racional e efeito emocional, completa este volume, Sebastião Lourenço dos Santos e Elena Godoy tomam como referência a teoria da relevância, as neurociências cognitivas e a psicologia cognitiva para propor uma arquitetura mental que congrega razão e emoções.

Enfim, com esta edição, é possível dizer que se cumpre o propósito de levar à sociedade estudos originais e inéditos que transbordam fronteiras continentais e linguísticas, além de realçar ainda mais a diversidade e a importância dos estudos linguísticos para a ciência.

\section{REFERÊNCIAS}

SIEBERT, Silvânia; DALTOÉ, Andréia da Silva. A ciência resiste. Linguagem em (Dis)curso - LemD, Tubarão, SC, v. 21, n. 2, p. 179-184, maio/ago. 2021.

FOUCAULT, Michel. A verdade e as formas jurídicas. Rio de Janeiro: Nau Editora, 1999.

SANTOS, Solange de Sousa. Ciência, discurso e mídia: a divulgação científica em revistas especializadas. 2007. Dissertação (Mestrado em Filologia e Língua Portuguesa) - Faculdade de Filosofia, Letras e Ciências Humanas, Universidade de São Paulo, São Paulo, 2007. doi:10.11606/D.8.2007.tde18032008-142546. Acesso em: 2021-11-22.

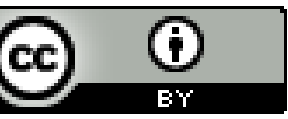

Este texto está licenciado com uma Licença Creative Commons Atribuição 4.0 Internacional. 